UDC 338.433:332.33:330.15-047-44

DOI: $10.15673 /$ fie.v10i4.1128

\author{
Nemchenko V. \\ Doctor of Economics, Professor \\ Department of Accounting and Auditing \\ E-mail: bossvalera29@gmail.com \\ Nemchenko H. \\ Assistant \\ Department of Management of Business \\ Odessa National Academy of Food Technologies \\ Kanatna str., 112, Odesa, Ukraine, 65039 \\ E-mail: annem2956@gmail.com
}

\title{
PROBLEMS OF THE LAND MARKET FORMATION AND THE ASSESSMENT OF NATURAL RESOURCES
}

The issues of formation of the land market and the role of the state in its regulation have been studied in the article. The great importance of the agrarian business (APC)'s reforming is placed on the land market. Its formation was carried out in all countries with economies in transition (CEIT). The necessity of a moratorium on land purchase and sale in present-day conditions in Ukraine has been proved. For Ukraine, the topicality of the solution of this problem lies in the fact that the country, on the one hand, has huge potential in food production, and, on the other hand, the theoretical and practical measures on the formation of the land market and the economic assessment of natural resources have not been fully developed yet. The aim of the research is to come to know the special aspects of the formation of the land market and factors that stop its development, and the development of a concept for the assessment of natural resources, including land ones. The concept of economic evaluation of natural resources, including land, has been developed. The authors believe that the assessment of natural resources should be determined by the cost of their reproduction. The faster the exhaustion of natural resources will occur, the more intense there should be changes in the structure of the country's economy.

Key words: land and natural resources assessment, land market, land market moratorium.

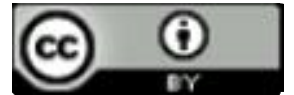

This work is licensed under a Creative Commons Attribution 4.0 International License http://creativecommons.org/licenses/by/4.0/
Statement of the problem and its connection with important scientific and practical tasks. The great importance of reforming the AIC (agro-industrial complex) is allocated precisely to the land market. Its formation was carried out in all emerging market countries. The topicality of the solution of this problem for Ukraine is that the country, on the one hand, has a huge potential in the production of food, and, on the other hand, the theoretical and practical measures on the formation of the land market and the economic assessment of natural resources have not been fully developed.

The analysis of the latest publications on the problem. Problems of the formation of the land market and its evaluation were reflected in the works of O.F. Balats'koho, B.M. Danilishyna, P.P. Sabluka, A.N. Asaula, O.M. Shpychaka and others. Despite a large number of scientific publications on the issue of assessing natural resources, including land and the formation of the land market - these problems remain unresolved today.

Forming of the aims of the research. The purpose of the study is to study the peculiarities of the formation of the land market and factors that hinder its development, and the development of a concept for the assessment of natural resources, including land.
Giving an account of the main results and their substantiation. It is a well-known fact that the land is the main instrument of production, place of residence and the condition of people's lives. At the same time, the land plays a role as the territory of the state, and therefore performs also a political function. Some scientists view land and natural resources as a capital. It is not surprising that people competed for the land and continue their struggle even now. The problem of land is extremely important for Ukraine.

There are 6.7 million citizens who own 31 million hectares of agricultural land and 10.5 million hectares are state-owned, but due to the moratorium, buying and selling land is prohibited in Ukraine [7]. Up to $90 \%$ of owners of land shares cannot independently cultivate land (by age, illness and other reasons), therefore, they have to rent it out. In 2017, the rent for 1 hectare was only $\$ 50$, while in Europe, \$ 250 [9, 10]. That's why, many people want to sell the land and there is a need for the market. Therefore, a significant number of politicians and scientists believe that the lack of a land market in Ukraine, a moratorium is a "rudiment of socialism", promotes single-purpose development of the village, constrains lending, and in the media there is already 
an advertisement of the benefits of selling farmland, which will contribute to the wealth of the peasants.

Western countries are also putting pressure on Ukraine. It emerges through international credit institutions (like IMF) which demand the introduction of a land market. Climate change, a significant increase of the population - all these put food supply security issues at the first place in the world. According to the leading Chinese researchers, national agriculture will not be able to provide all the needs of the population in food products, and the country will be forced to seek additional areas abroad. That is why the Ministry of Agriculture of the People's Republic of China (PRC) has developed a special state program that encourages Chinese companies to buy agricultural land outside the country [3, c.109].

Of course, a market economy involves the market, including land. But can the land market be implemented in Ukraine today and what does it represent?

The land market is part of the real estate market, which in its turn serves as a share of the investment market. Cycles in the development of the real estate market do not coincide with economic cycles. The decline in the real estate market is ahead of the decline of the economy as a whole, and the rise is faster. Therefore, the state of the real estate market can be concluded by the nature and trends in the economy: if the situation in the real estate market deteriorates, then the situation in the national economy is worsening over time, and vice versa [1, p.265]. The economy of Ukraine is in a permanent crisis and the standard of living is decreasing, which leads to the extinction of a significant population and the emigration of able-bodied, primarily young people.

Therefore, the prices of "the best black humus earth" will be lower than the world' ones. So the importance of the state usually grows, because it should control and regulate the land market, protect the owner, and plan the development of the economy in the future. According to Russian economist V.A. Horemykin: "State regulation of land relations is directed at the organization of rational use and protection of land by establishing certain rules and norms of possession, use and disposal of land resources of the country and their individual shares in order to consolidate and develop the country's economy in the interests of its people" [2, p. 670]. Unfortunately, the modern "oligarchic" state of Ukraine today is not capable of performing its functions. Despite the fight against corruption, raider hunts of business, land, harvests, construction in the protected areas and other violations continue.

In these conditions, if there is no moratorium, the agricultural holdings and oligarchs will buy the land, because for the average citizen and for the farmers the price will be unavailable, despite the fact that it will still be lower than the competitive prices. The right to purchase agricultural land should be recognized only by those peasants who live and work in the agro-industrial complex and have the appropriate training, pay taxes. Secure prospects for "land" colonization of Ukraine are recognized by leading Western economists. At the VIII European-Ukrainian Forum in February 2015, a French scientist Dominique Meno stated that Ukraine could permanently lose its historical roots as a result of the scourge and devaluation of the natural resources of rural areas [8]. It is impossible to have civilized functioning of the land market without an assessment, which is underestimated, the quality is better, while in developed countries, the quality is worse, and the price is many times higher than in Ukraine. That is why we consider the introduction of the land market as premature and possible only after economic reforms in the country. There is no relevant legislation as for land, and, first of all, for the assessment of natural resources in general, based on which the differential rent has been set since the Soviet era.

The history of economic thought of assessing natural resources, including land, began with Marx, continued in the middle of the twentieth century and remains open now. For example, academician Strumilin S.H. determined the assessment of the costs of land development and then decided to determine the assessment of land "by Marx" - through the rent. But this approach does not give an answer - how to estimate a land that does not rent? At present, it is unlawful to carry out an economic assessment of natural resources, taking into account only expenditures aimed at obtaining one or another resource, net income that occurs during this. Such an assessment, in our opinion, would be legitimate, when the level of production was negligible, natural resources seemed "inexhaustible", and nature itself without the help of an outsider could "heal" the wounds. In today's environment, the need to protect the environment, which has become the most important factor in the reproduction of natural resources, is exacerbated. K. Marx wrote: "Since needs exceed the quantity of products provided by nature, then the person remains forced to run into industrial production" [5, p.71.]. Already in the twentieth century it was proven that social reproduction includes not only the reproduction of material goods, labor and production relations, but also the natural environment.

Today there are "substitutes" of the land (hydroponics, aeroponics, etc.), widely traded technology for the cultivation and use of Californian earthworm, which can "produce" humus from agricultural waste. Moreover, some countries (Japan, Arab Emirates) create artificial islands inhabited by the population and engaged in agriculture. Urban agriculture has been developed on the roofs of high-rise buildings, and so on. That is why, as the resources of one or another source of natural resources are exhausted, society, without interrupting the production process, will be forced:

1) to spend resources on search, development of the less rich, located in the worst conditions of deposits (for example, on the sea shelf);

2) to find ways to meet the need for scarce resources through recycling and integrated resource utilization;

3) to explore the ability to reproduce these resources artificially (for reproducible resources) or, if this is impossible (for non-reproducible resources), to create their substitutes or to transport them from space in the future.

That's why to assess the consumption of reproducible natural resources, it is necessary to include costs not only for exploration and extraction, but also differen- 
tial income derived from their exploitation, absolute, monopoly rent, expenses aimed at preventing damage to the environment (we will define their full costs and designate them through C). If destruction (production) is subject to non-reproducible resources, then the assessment must include the costs of their substitutes. According to the proposed methodology, the unit of natural resource derived from the deposit $(\mathrm{P})$ will be calculated by the formula:

$$
P=C \div n+\left(E_{1}+E_{2}+E_{3}\right) \div n t
$$

Costs (variable payments) of enterprises for using a unit of natural resource $(\mathrm{A})$

Costs of the future, made by enterprises and accumulated by the state (constant payments) for the use of a unit of natural resources (B), where:

$\mathrm{n}$ - the value of the reserves in the natural expression (tons, $\mathrm{kg}$, etc.);

$E_{1}$ - means for search, development of less rich, located in the worse conditions of deposits (for example, on the sea shelf);

- ways to meet the need for scarce resources through recycling and integrated resource utilization;

$\mathrm{E}_{3}$ - the ability to reproduce resources artificially (for reproducible resources) or, if this is not possible (for non-reproducible resources) to create their substitutes or to transport them from space in the future;

C - Full expenses;

$\mathrm{t}$ - time, at the end of which there is a need for costs $\mathrm{E}_{1}, \mathrm{E}_{2}, \mathrm{E}_{3}[5, \mathrm{p} .17]$.

Costs A will only ensure the reproduction of the costs of extractive enterprises and "compensate" the damage from the environmental degradation of the deposit. They will depend on the reserves of the field, its quality, and the organization of labour in the extractive enterprises. That is why these costs can vary (we call them "variables"). Costs B will be allocated to artificial reproduction or replacement of one or another resource as it exhausts, to develop a new technology and some other activities.

It is precisely the costs B that can "compensate" for the "loss" of a resource that society needs. They can ensure the continuity of production in the future when the field is exhausted. In these costs society will have a constant need (we call them "permanent"). It is important not only to provide accumulation, but also to use the money received for its intended purpose (for reproduction of natural resources). The system of prices will become the battery of payments. In them, on a single methodological basis, costs will be taken into account for the reproduction of fixed assets, labour, natural resources, protection and reproduction of the environment.

The proposed assessment focuses on stimulation and will make it possible to improve the use of natural resources, reduce the losses caused by various factors, among them: mismanagement. It will also be an opportunity for business to develop and improve resource-saving leading technologies.

Since nowadays, in agricultural turnover worse soils get involved (the case when $t$ decreases), the cost of a hectare of farmland for the community will increase. The calculation must be differentiated taking into account the reproducibility of the resources.

Knowing the time at which one or another natural resource will be exhausted, a society in the conditions of market regulation will be able to coordinate the production activities of enterprises throughout the country, to form a fund for their reproduction. The sooner the traditional natural resources will be exhausted, the more intensive changes in the structure of the sectors of the national economy should take place. Otherwise, society may face a crisis in the use of certain or other natural resources. Therefore, countries which have commodity-driven economy should predict the period of use of natural resources and take measures to replace them in the future, which requires the formation of an innovative direction of development. It is no coincidence that today the countries of the Middle East reorient their economies from oil products to an innovative way, reducing the share of raw materials. O. Kovaliv also has a similar point of view. He believes that funds in the form of profit from the right to national ownership of natural resources should go to a rent bank and be credited to special accounts in the appropriate proportions: at the state level - 30\%, at the regional level $10 \%$ and in the district - $60 \%$ and used on reforms [4].

Conclusions and prospects of the further investigations. The offered method of estimation allows taking into account differentiated, absolute, monopoly rent. An assessment of natural resources will save labor or prevent losses in the future. If we know the time of exhaustion of each natural resource, we can form a fund for their reproduction. The faster the exhaustion of natural resources will occur, the more intensive there should be changes in the structure of the country's economy. The society must be required to move from the extensive lines of production to intensive ones. Inclusion of the proposed assessment of natural resources to the cost of production can reduce the profitability of enterprises, increase prices. However, this will be offset by reducing the cost of eliminating harm from inappropriate environmental management. The only way to reduce socially necessary production costs is to increase productivity. Of course, a state should be involved in the assessment of land, which would accumulate and create a fund for the restoration of land resources, control the content of humus and stimulate farmers not to harm the land. This will create conditions for increasing yields in the future, raising the competitiveness of the country.

\section{References}

1. Asaul, A. N. (2004). Èkonomika nedvižimosti. Piter: SPb.

2. Goremyikin, V. A. (2004). Ėkonomika nedvižimosti. Moskva: TK Velbi, Prospekt.

3. Kordzaia, N. R., \& Yehorov, B. V. (2018). Osnovnì ponâttâ prodovol'ćö̈ bezpeki kraïni. Herson: Oldì-plûs. 
4. Kovaliv, A. (2017, December 8). Suŝnost'zemel'nogo kapitala. Zerkalo Nedeli. Retrieved September 23, 2018, from https://zn.ua/macrolevel/suschnost-zemelnogo-kapitala-268776 .html

5. Marks, K., \& Engels, F. Niŝeta filosofii (2nd ed., Vol. 4). Retrieved September 23, 2018, from https://www.ereading.club/bookreader.php/1029811/Marks_-_Nischeta_filosofii.html.

6. Nemchenko, V. V. (1994). Formuvannâ ekonomičnogo mehanizmu racional'nogo vikoristannâ prirodnih resursìv v agropromislovomu kompleksì (teoriâ, metodologiâ, praktika). Kï̈v: Ìnstitut agrarnoï ekonomìi.

7. Tkachuk, A. (2017, November 10). Zemlâ i lûdi. Zerkalo Nedeli. Retrieved September 23, 2018, from https://zn.ua/ariculture/zemlya-i-lyudi-265049_.html

8. Chopenko, V. (2015, May 29). Kolybel'naâ dlâ sela. Zerkalo Nedeli. Retrieved September 23, 2018, from https://zn.ua/macrolevel/kolybelnaya-dlya-sela-_.html

9. Yakel, R. (2018, July 21). Rynok zemli: Otkryvat' ili podoždat'. Zerkalo Nedeli. Retrieved September 23, 2018, from https://zn.ua/business/rynok-zemli-otkryvat-ili-podozhdat-289627 .html

10. Stupen, M. H., Hulko, R. Y., \& Zalutskyi, I. R. (2005). Ocinka zemel'. Lvìv: Novij svìt-2000.

Received 30 September 2018

Approved 26 October 2018

Available in Internet 29.12.2018

Немченко В.В.

доктор экономических наук, професссор

кафедра учета и аудита

E-mail: bossvalera29@gmail.com

Немченко А.B.

ассистент

кафедра управления бизнесом

Одесская национальная академия пищевых технологий

ул. Канатная, 112, г. Одесса, Украина, 65039

E-mail: annem2956@gmail.com

\section{ПРОБЛЕМЫ ФОРМИРОВАНИЯ РЫНКА ЗЕМЛИ И ОЦЕНКА ПРИРОДНЫХ РЕСУРСОВ}

В статье рассмотрены вопросы фрормирования рынка земли и роли государства в его регулировании. Огромное значение в реформировании АПК отведено именно рынку земли. Его формирование осуществлялось во всех странах с переходной экономикой. Обоснована необходимость моратория купли-продажи земли в современных условиях в Украине. Для Украины, актуальность решения этой проблемы заключается в том, что страна с одной стороны имеет огромный потенциал в производстве продовольствия, а с другой, теоретические и практические мероприятия по формированию рынка земли и экономической оценки природных ресурсов не до конца разработаны. Целью исследования является изучение особенностей формирования рынка земли и факторов, сдерживающих его развитие, и разработка концепции оценки природных ресурсов, включая земельные. Разработана концепция экономической оценки природных ресурсов, включая и земельные ресурсы. Авторы считают, что оценка природных ресурсов должна определяться затратами на их воспроизведения.

Рынок земли - это составляющая рынка недвижимости, который в свою очередь выступает долей инвестиционного рынка. Циклы в развитии рынка недвижимости не совпадают с экономическими циклами. Спад на рынке недвижимости опережает спад экономики в целом, а подъем наступает быстрее.

Отсутствует соответствующее законодательство по земле и в первую очередь по оценке вообще природных ресурсов, в основу которых еще с советских времен, возложена дифференциальная рента. В настоящее время, неправомерно осуществлять экономическую оценку природных ресурсов, учитывая только расходы, направленные на получение того или иного ресурса, чистого дохода, возникающего при этом.

Предложенная оценка ориентирует стимулирования и сделает возможным улучшить использование природных ресурсов, уменьшение убытков, вызванных различными фракторами, среди них: бесхозяйственность. Также станет возможность для бизнеса разработка и усовершенствование ресурсосберегающих передовых технологий.

Чем быстрее будет происходить исчерпания природных ресурсов, тем интенсивнее должны быть изменения в структуре экономики страны.

Ключевые слова: оценка земли и природных ресурсов, рынок земли, мораторий рынка земли. 


\author{
Немченко В.В. \\ доктор економічних наук, професор \\ кафедра обліку та аудиту \\ E-mail: bossvalera29@gmail.com \\ Немченко Г.В. \\ асистент \\ кафедра управління бізнесом \\ Одеська національна академія харчових технологій \\ вул. Канатна, 112, м. Одеса, Україна, 65039 \\ E-mail: annem2956@gmail.com
}

\title{
ПРОБЛЕМИ ФОРМУВАННЯ РИНКУ ЗЕМЛІ ТА ОЦІНКА ПРИРОДНИХ РЕСУРСІВ
}

У статті розглянуті питання формування ринку землі і ролі держави у його регулюванні. Важливе значення у рефрормуванні АПК відведено саме ринку землі. Його формування здійснювалось в усіх країнах з перехідною економікою. Обґрунтована необхідність мораторію купівлі-продажу землі у сучасних умовах в Україні. Для України, актуальність вирішення цієї проблеми полягає у тому, що країна з одного боку має величезний потенціал у виробництві продовольства, а з іншого, теоретичні та практичні заходи щодо формування ринку землі та економічної оцінки природних ресурсів не до кінця розроблені. Метою дослідження $є$ вивчення особливостей формування ринку землі і чинників, які стримують його розвиток, та розробка концепції оцінки природних ресурсів, включаючи земельні. Розроблена концепція економічної оцінки природних ресурсів, включаючи і земельні. Автори вважають, що оцінка природних ресурсів повинна визначатися витратами на їх відтворення.

Ринок землі - це складова ринку нерухомості, який у свою чергу виступає часткою інвестиційного ринку. Цикли у розвитку ринку нерухомості не співпадають з економічними циклами. Спад на ринку нерухомості випереджує спад економіки у цілому, а підйом наступає швидше.

Відсутнє відповідне законодавство по землі і в першу чергу з оцінки взагалі природних ресурсів, в основу яких, ще з радянських часів, покладена диференційна рента. У теперішній час, неправомірно здійснювати економічну оцінку природних ресурсів, враховуючи тільки витрати, спрямовані на одержання того або іншого ресурсу, чистого доходу, що виникає при цьому.

Запропонована оцінка орієнтує стимулювання та зробить можливим покращити використання природних ресурсів, зменшення збитків, які спричиняються різними чинниками, серед них: безгосподарність. Також стане можливість для бізнесу розробка і удосконалення ресурсозберігаючих провідних технологій.

Чим швидше буде відбуватись вичерпання природних ресурсів, тим інтенсивніше повинні бути зміни у структурі економіки країни.

Ключові слова: оцінка землі та природних ресурсів, ринок землі, мораторій ринку землі.

\section{Література}

1. Асаул А.Н. Экономика недвижимости: навч. посіб. СПб.: Питер, 2004. 512 с.

2. Горемыкин В.А. Экономика недвижимости: навч. посіб. М.: ТК Велби, Проспект, 2004. 848 с.

3. Кордзая Н.Р., Сгоров Б.В. Основні поняття продовольчої безпеки країни: монографія. Херсон.: Олдіплюс, 2018. 148 с .

4. Ковалив А. Сущность земельного капитала // Зеркало недели: электрон. версия газ. 2017. № 1172. 8 дек. URL https://zn.ua/macrolevel/suschnost-zemelnogo-kapitala-268776_html (дата звернення: 23.09.2018)

5. Собрание сочинений К. Маркса, Ф. Энгельса: в 50 т. Т. 4. Нищета философии. 2-е изд., С. 65-185. URL: https://www.e-reading.club/bookreader.php/1029811/Marks_- Nischeta filosofii.html (дата звернення: 23.09.2018)

6. Немченко В.В. Формування економічного механізму раціонального використання природних ресурсів в агропромисловому комплексі (теорія, методологія, практика): автореф. дис. ... д.е.н.: 08.00.05, 08.00.15: захист 29.03.1994/ наук. кер. Паламарчук В.О. / Київ: Інститут аграрної економіки, 1994. 36 с.

7. Ткачук А. Земля и люди // Зеркало недели: электрон. версия газ. 2017. № 11664. 10 ноября. URL: https://zn.ua/ariculture/zemlya-i-lyudi-265049 .html (дата звернення: 23.09.2018) 
8. Чопенко В. Колыбельная для села // Зеркало недели: электрон. версия газ. 2015. 29 мая Retrieved from:https://zn.ua/macrolevel/kolybelnaya-dlya-sela-.html (дата звернення: 23.09.2018)

9. Якель Р. Рынок земли: открывать или подождать // Зеркало недели: электрон. версия газ., 2018. №1203. 21 июля-10 августа. URL: https://zn.ua/business/rynok-zemli-otkryvat-ili-podozhdat-289627 html (дата звернення: 23.09.2018)

10. Оцінка земель: навч.посіб. / Ступень М.Г., Гулько Р.Й., Залуцький І.Р. та ін. Львів: Новий світ2000, 2005. 308 c.

Стаття надійшла 30.09.2018 Стаття прийнята до друку 26.10.2018 Доступно в мережі Internet 29.12.2018

Цитування згідно ДСТУ 8302:2015

Nemchenko V., Nemchenko H. Problems of the land market formation and the assessment of natural resources // Food Industry Economics. 2018. Vol.10, Issue 4. P. 9-14. doi: 10.15673/fie.v10i4.1128

Cite as APA style citation

Nemchenko V., \& Nemchenko H. (2018). Problems of the land market formation and the assessment of natural resources. Food Industry Economics, 10(4), 9-14; doi: 10.15673/fie.v10i4.1128 